\title{
DENGUE, EL CASTIGO DE SÍSIFO EN PARAGUAY
}

\section{Osvaldo MEZA ${ }^{1}$.}

${ }^{1}$ Médico internista. Editor de Ciencias Médicas y Salud y columnista de la revista Ciencia del Sur, Asunción - Paraguay.

Cómo citar este artículo: Meza O. Dengue, el castigo de Sísifo en Paraguay. Medicina Clínica y Social. 2018;2(1):2-5.

La leyenda dice que Sísifo, siendo un astuto mortal, llegó a fastidiar a los dioses griegos de un modo tal que estos decidieron castigarlo. El castigo consistía en subir una monumental roca a una montaña de manera que, al intentar llegar a la cúspide, volvería a caerse y el castigo comenzaría de nuevo una y otra vez.

Es así como podría describirse la situación de Paraguay con respecto al dengue, hoy día considerado endémico en el país por las autoridades sanitarias, pero con brotes cíclicos cada cierto tiempo.

Del dengue se ha dicho ya tanto en estos últimos días que aparentemente está demás repetir lo mismo, pero en vista a la aparición de más y más casos, parece que en este tema nunca se exagera. Mientras nuestro propio castigo de Sísifo siga siendo un problema de salud pública, compete a toda la ciudadanía seguir informándose.

El dengue es el paradigma de enfermedad tropical, además de ser la más frecuente del mundo según cifras de la Organización Mundial de la Salud (OMS).

En los últimos 50 años su incidencia ha aumentado 30 veces con la creciente expansión geográfica hacia nuevos países y de áreas urbanas a rurales. Anualmente se detectan 50 millones de infecciones por dengue y unas 2,5 mil millones de personas viven en países con dengue endémico.

Según declaraciones del Premio Nacional de Ciencias 2010, el Dr. Antonio Arbo, el primer gran brote de dengue en Paraguay se registró en 1989. A partir de 2000, como lo describe la epidemiología, han reaparecido brotes cada 3 o 4 años. El Ministerio de Salud ha lanzado sus programas de contingencia, encontrándose en 2007 con el serotipo 3, con algunos casos fatales, atribuidos al dengue.

Posteriormente aparecerían en 2013, 2016 y, por último, este año, en todas estas temporadas con víctimas también fatales (1).

En vista a los continuos fracasos del Ministerio de Salud Pública y Bienestar Social en prevenir nuevos brotes o minimizar su impacto, una cosa es cierta: si no es el Estado, la responsabilidad 
de la salud pública recae sobre la propia ciudadanía. Por lo que es muy difícil exagerar la importancia de obtener y aplicar la información adecuada para disminuir al mínimo los nuevos casos o, en caso de haber contraído la enfermedad, intentar una rápida y pronta recuperación.

\section{¿Qué es realmente el dengue?}

El dengue es una enfermedad producida por un virus de la familia Flaviviridae, género Flavivirus y del cual existen 4 serotipos. Por ejemplo, la epidemia de este año (2018) se debe al serotipo 1 , el más benigno. Como se sabe, el virus se transmite a través de los mosquitos Aedes aegypti y Aedes albopictus, por lo que la eliminación de los criaderos de los mosquitos es fundamental en la prevención de la propagación del virus.

Un detalle interesante es que el aumento global de las temperaturas ha hecho que el período de incubación del mosquito se acorte, por lo que tienden a proliferar con más rapidez. Tal vez esa sea una de las causas del aumento de nuevos casos (2).

\section{¿Cómo adquiere el virus el mosquito?}

Cuando la hembra del mosquito succiona sangre de un paciente ya enfermo de dengue que se encuentra en la fase febril de la enfermedad, ya que en esta fase el virus circula en la sangre.

Posteriormente, el virus se incuba en el mosquito durante 4 a 10 días, luego ya se convierte en transmisor durante toda su vida, que puede llegar hasta los dos meses.

Una vez que el paciente es inoculado con el virus a través de la picadura del mosquito vector, demora nuevamente entre 7 a 10 días en manifestarse la enfermedad (3).

\section{¿Cómo se diagnostica la enfermedad?}

El diagnóstico se basa preponderantemente en la clínica: fiebre de aparición reciente junto con dolores musculares y óseos generalizados además de una prueba de laboratorio, que se realiza a partir del suero del paciente, o sea, una muestra de sangre. La más popular es la prueba de detección del antígeno NS1, bastante específica y que ya puede ser positiva a pocas horas de haberse iniciado los síntomas.

El inicio de la enfermedad se caracteriza por fiebre alta (inclusive hasta $40^{\circ} \mathrm{C}$ ) y dolores articulares, musculares y la típica cefalea retroocular, de ahí el nombre de "fiebre rompehuesos". Ésta constituye la fase febril de la enfermedad, que puede durar de 3 a 5 días. Desconcierta en cierta medida el diagnóstico mismo, ya que el médico puede saber muy bien cuándo empieza la enfermedad, pero no cuánto durará ni cuándo o cómo terminará.

Posteriormente se inicia la fase crítica, en la que paradójicamente cesan la fiebre y los malestares, por lo que es común pensar que uno ya está curado. El nombre de esta fase se debe a que coincide cronológicamente con el daño producido por el virus al endotelio capilar (células que tapizan el interior de los vasos sanguíneos) y a la médula ósea, con la consecuente fuga capilar (esto es, desplazamiento del plasma a un compartimiento fuera del vascular) y una 
disminución de los glóbulos blancos (células del sistema inmune) y las plaquetas (encargadas de la coagulación de la sangre).

Son estos dos efectos (fuga capilar y disminución de plaquetas) los que acabarán determinando los signos de alarma, que a su vez sirven para clasificar la enfermedad y su manejo. Es durante la fase crítica cuando los controles de hemograma se vuelven más frecuentes, dependiendo del estado del paciente. Si el paciente está estable, los controles pueden ser más laxos, de hasta 48 horas, si está grave, por lo menos cada 12 horas.

Típicamente los signos de alarma son: náuseas y vómitos (más de tres veces en menos de una hora), la incapacidad de ingerir líquidos, letargia, dolor abdominal intenso, sangrado de piel o de mucosas, plaquetas menores a $100.000 / \mathrm{mm} 3$ y un aumento importante de enzimas hepáticas. La aparición de estos signos constituye una indicación para la internación del paciente (la fiebre no es un signo de alarma).

Esta fase nuevamente dura 3 a 5 días y es el período en el que la enfermedad puede derivar o a un cuadro grave o a su resolución, pasando por último a una fase de recuperación de 48 a 72 horas que se caracterizan por una mejoría clínica y un ascenso de las plaquetas (4).

El tratamiento del dengue consiste en una hidratación adecuada al peso y la edad del paciente, de manera a atenuar los efectos de la fuga capilar, y un tratamiento sintomático - las molestias ocasionadas por la fiebre. No se prescribe un tratamiento específico para la fiebre si ésta no presenta molestias y es poco realista pretender no tener fiebre justamente en la fase febril.

\section{¿Qué medicamentos se utilizan?}

Actualmente solo dos medicamentos están aprobados para el tratamiento de estos síntomas, a saber, el paracetamol y la dipirona, siempre respetando sus dosis máximas recomendadas.

No existe tratamiento comprobado alguno para aumentar el número de plaquetas o para los demás signos de alarma. Se están realizando investigaciones serias con el extracto de las hojas del mamón, pero la evidencia no es concluyente $(5,6)$. La vacuna contra el dengue se recomienda a pacientes que ya han padecido la enfermedad por lo menos una vez y no presentan contraindicaciones.

Las recomendaciones de los organismos gubernamentales siguen vigentes. Ante la aparición de los síntomas y signos mencionados, se recomienda acudir al médico. Éste tiene el deber de clasificar su caso en tres tipos: 1) dengue con signos de alarma; 2) dengue sin signos de alarma o 3) dengue grave. De esta clasificación dependerá que el tratamiento sea ambulatorio (en la casa), si quedará en observación por unas horas o si amerita la internación.

Se aconseja a la ciudadanía que se informe sobre la enfermedad y sobre el tratamiento científicamente verificado y sobre todo a trabajar en la prevención de la misma eliminando el vector, porque sin mosquito no hay enfermedad. Cualquier tratamiento que ofrezca una pronta remisión del cuadro o un incremento súbito de las plaquetas no cuenta actualmente con el respaldo científico y debe ser desestimado. 
Sísifo no pudo librarse de su imperturbablemente rutinario castigo, pero hoy contamos con educación y ciencia que, de ser aplicadas de manera integral, pueden ayudarnos a mover esta gran roca del dengue con mucha más facilidad y la menor molestia posibles, si es que no nos libra por completo de este flagelo.

\section{CONFLICTOS DE INTERÉS Y FUENTE DE FINANCIACIÓN}

El autor declara no poseer conflictos de interés. Fuente de financiación: ninguna.

\section{REFERENCIAS BIBLIOGRÁFICAS}

1. $A B C$ Color. Arbo acusa de negligente al sistema de salud por el dengue - Edición Impresa ABC Color. [citado 7 de marzo de 2018]. Disponible en: http://www.abc.com.py/edicion-impresa/politica/arbo-acusa-de-negligente-al-sistema-de-salud-por-el-dengue-1680141.html

2. Dengue: guías para el diagnóstico, tratamiento, prevención y control. [citado 7 de marzo de 2018]. Disponible en: https://www.mspbs.gov.py/dependencias/imt/adjunto/e347a4-dengueCONTROL.pdf

3. OMS | Dengue y dengue grave. WHO. [citado 8 de marzo de 2018]. Disponible en: http://www.who.int/mediacentre/factsheets/fs117/es/

4. Dengue: abordaje inicial y tratamiento. [citado 8 de marzo de 2018]. Disponible en: https://www.mspbs.gov.py/dependencias/imt/adjunto/b5a976-Dengue2.pdf

5. Ahmad N, Fazal H, Ayaz M, Abbasi BH, Mohammad I, Fazal L. Dengue fever treatment with Carica papaya leaves extracts. Asian Pac J Trop Biomed. 2011;1(4):330-333. https://doi.org/10.1016/S2221-1691(11)60055-5

6. Hettige S. Guidelines in using carica papaya leaf extract for Dengue fever patients. BMJ 2015;351. https://doi.org/10.1136/bmj.h4661 


\section{DENGUE, THE PUNISHMENT OF SISYPHUS IN PARAGUAY}

\section{Osvaldo MEZA ${ }^{1}$.}

${ }^{1}$ Internist. Editor of Medical Sciences and Health and columnist of Ciencia del Sur journal, Asunción Paraguay.

How to cite this article: Meza O. Dengue, el castigo de Sísifo en Paraguay. Medicina Clínica y Social. 2018;2(1):2-5.

The legend says that Sisyphus, being a cunning mortal, came to annoy the Greek gods in such a way that they decided to punish him. The punishment was to climb a monumental rock to a mountain so that, when trying to reach the top, it would fall again, and the punishment would start over and over again.

This is how the situation in Paraguay could be described with regard to dengue, which is now considered endemic in the country by health authorities, but with cyclical outbreaks every so often.

A lot has been said about dengue lately, and adding more can seem exhausting, but in view of the emergence of more and more cases, it seems that there is never enough said about this issue. As long as our own punishment of Sisyphus remains a public health problem, it is up to all citizens to continue to be informed.

Dengue is the paradigm of tropical disease, as well as being the most common one in the world according to figures from the World Health Organization (WHO).

In the last 50 years its incidence has grew 30 times with the increasing geographic expansion towards new countries and urban to rural areas. 50 million of dengue infections are detected annually and some 2.5 billion people live in countries with endemic dengue.

According to statements by the National Science Prize 2010, Dr. Antonio Arbo, the first major outbreak of dengue in Paraguay was recorded in 1989. As of 2000, sprouts have reappeared every 3 or 4 years. The Ministry of Health has launched its contingency programs, and in 2007 found the serotype 3 , with some cases fatal cases, attributed to dengue.

Later they would appear in 2013, 2016 and, finally, this year, in all these seasons with fatal victims (1).

In view of the continued failures of the Ministry of Public Health and Social Welfare to prevent new outbreaks or minimize their impact, one thing is certain: if it is not the state, the responsibility of public health falls on the citizenship itself. So it is very difficult to exaggerate the importance of obtaining and applying the appropriate information to minimize the new cases or, in case of having contracted the disease, to obtain a quick and prompt recovery. 


\section{What is dengue really?}

Dengue is a disease caused by a virus of the family Flaviviridae, genus Flavivirus and of which there are 4 serotypes. For example, this year's epidemic (2018) is due to serotype 1 , the most benign. As is known, the virus is transmitted through the mosquitoes Aedes aegypti and Aedes albopictus, so the elimination of mosquito breeding is fundamental in preventing the spread of the virus.

An interesting detail is that the overall increase in temperatures has made the incubation period of the Mosquito shorter, so they tend to proliferate more quickly. Perhaps that is one of the causes of the increase in new cases (2).

\section{How does the mosquito acquire the virus?}

When the female of the Mosquito sucks blood from a patient already sick with dengue who is in the febrile phase of the disease, because in this phase the virus circulates in the blood.

Subsequently, the virus incubates in the mosquito for 4 to 10 days, then it becomes a transmitter for a lifetime, which can reach up to two months.

Once the patient is inoculated with the virus through the mosquito vector bite, it takes 7 to 10 days for the disease to manifest again (3).

\section{How is the disease diagnosed?}

The diagnosis is based predominantly by the clinical presentation: fever of recent onset along with generalized muscular and bony pain in addition to a laboratory test, which is done from the patient's serum, or a blood sample. The most popular is the NS1 Antigen screening test, which is quite specific and can already be positive within a few hours of the onset of the symptoms.

The onset of the disease is characterized by high fever (up to $40^{\circ} \mathrm{C}$ ) and muscular and osteoarticular pain, and the typical retro-ocular headache, hence the name of "bone-breaking fever". This constitutes the febrile phase of the disease, which can last from 3 to 5 days. The presentation itself can be baffling, as the doctor may know very well when the disease starts, but not how long it will last or when or how it will end.

Later the critical phase begins, in which paradoxically the fever and the aches cease, so it is common to think that one is already cured. The name of this phase is because it coincides chronologically with the damage caused by the virus to the capillary endothelium (cells that upholster the inside of the blood vessels) and to the bone marrow, with the consequent capillary leakage (that is, displacement of the plasma to a compartment outside the vascular compartment) and a decrease in white blood cells (cells of the immune system) and platelets (responsible for blood clotting).

These two effects (capillary leakage and platelet reduction) will end up determining the alarm signs, which in turn serve to classify the disease and its management. It is during the critical 
phase when the blood count controls become more frequent, depending on the patient's condition. If the patient is stable, the controls may be laxer, up to 48 hours, if severe, at least every 12 hours.

Typically, the signs of alarm are: nausea and vomiting (more than three times in less than one hour), inability to ingest fluids, lethargy, severe abdominal pain, skin or mucosal bleeding, platelet count lower than $100,000 / \mathrm{mm} 3$ and a significant increase in liver enzymes. The appearance of these signs constitutes an indication for the patient's hospitalization (fever is not a sign of alarm).

This phase lasts 3 to 5 days and is the period in which the disease can resolve or worsen. Lastly, a recovery phase of 48 to 72 hours is characterized by clinical improvement and increase of the platelet count (4).

The treatment of dengue is hydration adequate to the weight and age of the patient so as to attenuate the effects of capillary leakage, and a symptomatic treatment of the discomfort caused by fever. A specific treatment for fever is not prescribed if it does not present discomfort and it is unrealistic to pretend not to have fever precisely in the febrile phase.

\section{What medications are used?}

Currently only two drugs are approved for the treatment of these symptoms, namely, paracetamol and dipyrone, always considering their recommended maximum doses.

There is no proven treatment to increase the number of platelets or other signs of alarm. Serious investigations are being conducted with the extract of the leaves of papaya, but the evidence is inconclusive $(5,6)$. Dengue vaccine is recommended for patients who have already suffered the disease at least once and have no contraindications.

The recommendations of the government agencies remain in force. In the presence of the symptoms and signs mentioned, it is recommended to go to the doctor. The physician then will classify the case into three types: 1) dengue with signs of alarm; 2) dengue without signs of alarm or 3) severe dengue. According to this classification, the physician will initiate outpatient treatment, he will keep the patient in observation for a few hours or admit the patient to the hospital.

The citizens are advised to report the disease and the treatment received, and especially to work on preventing it by eliminating the vector, because the mosquito there is no disease. Any treatment that offers prompt remission or a sudden increase in platelets does not currently have scientific backing and should be dismissed.

Sisyphus could not get rid of his punishment, but today we have education and science that, if applied in an integral way, can help us move this great rock of dengue with much more ease, and maybe even get rid of this scourge completely. 


\section{CONFLICTS OF INTEREST AND FUNDING}

Conflicts of interest: none. Funding source: none.

\section{REFERENCES}

1. $A B C$ Color. Arbo acusa de negligente al sistema de salud por el dengue - Edición Impresa ABC Color. [citado 7 de marzo de 2018]. Disponible en: http://www.abc.com.py/edicion-impresa/politica/arbo-acusa-de-negligente-al-sistema-de-salud-por-el-dengue-1680141.html

2. Dengue: guías para el diagnóstico, tratamiento, prevención y control. [citado 7 de marzo de 2018]. Disponible en: https://www.mspbs.gov.py/dependencias/imt/adjunto/e347a4-dengueCONTROL.pdf

3. OMS | Dengue y dengue grave. WHO. [citado 8 de marzo de 2018]. Disponible en: http://www.who.int/mediacentre/factsheets/fs117/es/

4. Dengue: abordaje inicial y tratamiento. [citado 8 de marzo de 2018]. Disponible en: https://www.mspbs.gov.py/dependencias/imt/adjunto/b5a976-Dengue2.pdf

5. Ahmad N, Fazal H, Ayaz M, Abbasi BH, Mohammad I, Fazal L. Dengue fever treatment with Carica papaya leaves extracts. Asian Pac J Trop Biomed. 2011;1(4):330-333. https://doi.org/10.1016/S2221-1691(11)60055-5

6. Hettige S. Guidelines in using carica papaya leaf extract for Dengue fever patients. BMJ 2015;351. https://doi.org/10.1136/bmj.h4661 